\title{
Improved waste-activated sludge dewatering using sludge/oil emulsion, ultrasonic and microwave technologies
}

\author{
S Kim¹, J Kim² and J Chung ${ }^{3 *}$ \\ 'Environmental Engineering Dept., Samsung Engineering Co. Ltd, 500 SAMSUNG GEC, Sangil-Dong, Gangdong-Gu, Seoul, 134-728, Republic of Korea \\ ${ }^{2}$ Dept. of Civil and Environmental Engineering, Hanyang University, 222 Wangsimni-Ro, Seongdong-Gu, Seoul 133-791, Republic of Korea \\ ${ }^{3} R \& D$ Center, Samsung Engineering Co. Ltd, 415-10 Woncheon-Dong, Suwon, Gyeonggi-Do 443-823, Republic of Korea
}

\section{ABSTRACT}

Conventional dewatering technologies, such as centrifuges, belt filter presses, and rotary vacuum filters, are not effective methods for treating sewage sludge with high water content. This study evaluated the field-scale feasibility of new technologies that use emulsion, ultrasonication, and microwaves to dewater sludge. Emulsion technology lowered the water content in sludge to $60 \%$, but the overall process was too complex to incorporate into the design of commercial plants due to the requirement for oil- and methanol-recovery facilities. Ultrasonication had low dewatering and energy efficiency with long irradiation times, indicating that it would be difficult to implement in a field plant. The water content of sludge was reduced to $60 \%$ within $120 \mathrm{~s}$ using microwaves, but dewatering efficiency depended on the thickness and volume of the sludge. In a pilot-scale test, the average energy consumption was $0.54 \mathrm{kWh} / \mathrm{kg}$ of water removed, and the final water content of the sludge cake reached $60 \%$ within $30 \mathrm{~min}$.

Keywords: emulsion, energy efficiency, microwave, sludge dewatering, ultrasonication

\section{INTRODUCTION}

In recent years, the production of waste-activated sludge in municipal wastewater treatment plants has increased significantly. Treatment and disposal methods for municipal wastewater sludge include landfilling, ocean disposal, incineration, and composting, but direct landfills have been banned since July 2003 (MOE, 2003), and ocean disposal was outlawed in January 2012 (MOF, 2009). Thus, the recycling of sludge has been encouraged (e.g., composting, raw material for cement, and cover soil for landfilling), which is a prerequisite for reducing sludge volume and weight.

Sludge dewatering is a fundamental step in sludge processing because it decreases sludge volume and consequently the cost of transporting the sludge to its final disposal site. However, the high water content and biological gel-like structure of sludge render it difficult to dewater. Thus, suitable sludge conditioning processes should be performed before sludge dewatering. The moisture content of municipal wastewater sludge must be reduced significantly before its incineration and composting. Except for the drying method, however, existing technologies have technical limitations. The water content of activated sludge can be decreased to approximately $80 \%$ with existing mechanical dewatering technologies. To this end, various methods have been proposed to improve sludge dewaterability, such as the addition of acids and surfactants, Fenton's reagent pre-treatment, fungal treatment, ultrasonication, and microwave irradiation (Chen et al., 2001; Eskicioglu et al., 2007; Fakhru'l-Razi and Molla, 2007; Tony et al., 2008; Feng et al., 2009a; 2009b; Yu et al., 2009).

\footnotetext{
To whom all correspondence should be addressed.

용 +82-31-260-6053; Fax: +82-31-260-3800;

e-mail: jin-wook.chung@samsung.com

Received 4 February 2014; accepted in revised form 7 October 2014.
}

Chemical conditioning is a tactic that improves mechanical dewatering, flocculating the sludge with conditioners, such as calcium oxide, ferric chloride, and polyacrylamide (Chen et al., 2001). Also, thermal and thermochemical processes and chemical oxidation using hydrogen peroxide can enhance cake dewaterability in two ways: (i) they degrade extracellular polymeric substances (EPS) proteins and polysaccharides reducing the water retention properties; and (ii) they promote flocculation which reduces the amount of fine flocs (Neyens et al., 2004). However, the operating cost for sludge dewatering by these methods is relatively expensive compared to that for conventional transportation and disposal (Chitikela and Dentel, 1998; Lee and Liu, 2001; Dentel, 2010).

Alternatively, dewatering technologies using ultrasonic, electro-osmotic, and microwave treatments have been examined (Raats et al., 2002; Dewil et al., 2006; Na et al., 2007; Huan et al., 2009; Feng et al., 2009a). Na et al. (2007) observed that ultrasonic treatment of waste-activated sludge improved the dewaterability, as evidenced by decreases in capillary suction time (CST) with increasing ultrasonic energy dosages. Feng et al. (2009a) reported that low-energy dosage slightly enhanced sludge dewaterability, while high-energy dosage significantly decreased sludge dewaterability in ultrasonic treatment; the optimal energy dosage generated sludge with optimal EPS concentration and particle size distribution. Also, Dewil et al. (2006) reported that the dewaterability decreases with increasing specific energy. The rate of dewatering also decreases, as evidenced by a higher CST.

Industrial use of microwave heating as an alternative to conventional heating methods in chemical reactions is becoming popular, primarily due to its dramatic reactions and reaction times (Eskicioglu et al., 2007). Many studies have analysed the effects of microwave irradiation on biological and chemical systems using various microwave and conventional heating units and experimental techniques and approaches. In particular, Eskicioglu et al. (2007) observed that a thermal microwave 
enhances the digestibility of waste-activated sludge. Yu et al. (2009) reported that microwave irradiation improves sludge dewaterability at various microwave powers and exposure times. Moreover, microwave irradiation, followed by alkaline and polyelectrolyte dosing (combined conditioning), enhances the dewaterability of sludge and reduces the organic matter burden in sludge liquor (Wojciechowska, 2005; Doğan and Sanin, 2009). However, there has been little practical application of microwaves for sludge dewatering due to the shortage of reliable data for design and operating factors.

In this study, alternative technologies for the dewaterability of sludge, including sludge/oil emulsion, ultrasonication, and microwave irradiation, were examined, and their dewatering efficiencies were compared under various design and operational conditions using lab-scale and pilot-scale plants. Also, we evaluated the possibility of their practical application with regard to process scheme, process control, and operating cost.

\section{MATERIALS AND METHODS}

\section{Sludge samples}

Thickened sludge from a municipal wastewater treatment plant was used. Its moisture content was approximately $96 \pm 2 \%$, although this varied slightly with sampling time. Because the moisture content of sludge can decrease over time and affect the reproduction of the test, the collected sludge was refrigerated immediately, and all experiments were conducted within 4 days of sampling to avoid any degradation of the samples.

\section{Sludge dewatering using diesel emulsion}

The emulsion test equipment comprised a mixer to mix the sludge, diesel, surfactants, a pressurised filtering device to separate solid-phase sludge, and a vacuum drier. Methanol was used as a low boiling-point solvent for oil recovery. The mixer had $2 \ell$ of working volume, an agitator and heating jacket to maintain temperature. The container was constructed to facilitate sampling and analysis. The sludge, diesel, and surfactant were weighed at a specific ratio into a container, and the mixture was placed in a reactor that was kept at constant temperature for approximately $20 \mathrm{~min}$, for the reactant temperature to reach a specified point, and agitated. After an emulsion was formed, $75 \mathrm{~g}$ of methanol was added to the emulsion to replace diesel. The surfactants used in this study were of 4 types: amphoteric (Miranol, Rhodia, USA), anionic (TROTON X-301, Dow Chemical Company, Korea), emulsifier (Danisco, DuPont, Japan), and polymeric (DEMOL NL, Kao Chemicals, Japan).

The pressure filter (Millipore Hazardous Waste Pressure Filter System, Millipore Co., Korea) was used to separate solid-phase sludge from the filtered liquid using $202.7 \mathrm{kPa}$ dry air and a glass microfibre filter (GF/C, $1.2 \mu \mathrm{m}$ pore size, Whatman). The moisture content of the separated solids was analysed on a Karl Fisher Volumetric Blending Titrator (Orion Turbo 2, Thermo Fisher Scientific Co., Korea). The measurement of residual solids followed preparation by drying for $24 \mathrm{~h}$ using a vacuum dryer (VC-3600, TITEC, Japan) $\left(60^{\circ} \mathrm{C}, 26.7 \mathrm{kPa}\right)$. The evaporated amounts of diesel and moisture were determined using a liquid nitrogen trap (CT100, Edwards, Japan) placed between dryer and vacuum pump (ED200, Edwards, Japan).

\section{Sludge dewatering using ultrasonic waves}

This experiment was performed in a batch reactor that was equipped with a disk transducer (Allied Signal Inc., Morristown, NJ), operating at $40 \mathrm{kHz}$. The disk transducer was fixed to the bottom of a cylindrical reactor with internal diameter of $240 \mathrm{~mm}$, height of $240 \mathrm{~mm}$, and working volume of $10 \mathrm{l}$. During the 120 -min sonication time, sludge samples were mixed completely by the agitator $(250 \mathrm{r} / \mathrm{min})$, and the temperature was maintained at $25 \pm 2^{\circ} \mathrm{C}$ by thermostatted jackets to prevent rises in temperature after sonication. The maximum ultrasonic input power was $0.5 \mathrm{~kW}$ and determined by calorimetric measurement (Mason, 1991). Power density and sonication intensity were $0.81 \mathrm{~W} / \mathrm{m} \ell$ and $6.7 \mathrm{~W} / \mathrm{cm}^{2}$, respectively. The ultrasonicator can continuously monitor the amount of energy in joules as the energy is delivered to the disk transducer and can terminate the ultrasonic input when the desired amount of energy has been dispensed. After sonication, dewatering efficiency was measured using the same pressure filter as in the emulsion experiment.

\section{Feasibility of sludge dewatering using microwaves}

A household microwave oven (Samsung Electronics Co., frequency $2.45 \mathrm{GHz}$, max power $1.0 \mathrm{~kW}$ ) was used to generate microwave irradiation, in the middle of which a Pyrex vessel $(133 \mathrm{~mm} \times 250 \mathrm{~mm} \times 50 \mathrm{~mm})$ was installed. The sludge temperature was measured with a thermocouple probe (T-type, Labcor Technical Sales Inc., ON, Canada), inserted into the middle of the sample and connected to a module for analogue-to-digital conversion, and recorded on a laboratory computer system (LabVIEW Software Version 6, National Instruments Co., Austin, TX, USA). The microwave switch was used to adjust the microwave energy and turn the microwave on and off.

The sludge samples were prepared with various depths and widths. The microwave energy was adjusted from $0.2 \mathrm{~kW}$ to $1.0 \mathrm{~kW}$ for various durations $-0 \mathrm{~s}, 15 \mathrm{~s}, 30 \mathrm{~s}, 45 \mathrm{~s}$, and $60 \mathrm{~s}$. The treated samples were then cooled to room temperature before analysis. After the microwave treatment, dewatering efficiency was measured using the same pressure filter as in the emulsion experiment.

\section{Lab-scale test of sludge dewatering using microwaves}

A single chamber was designed by computer simulation, consisting of a chamber and power supply area. The wave guide and chamber were welded to block leakage of electromagnetic waves. Because irregular surfaces disturb the electromagnetic field, the chamber was welded from the outside. Further, the bridge between the magnetron and wave guide was designed to block leakage of the electromagnetic field. The power supply was placed at the top of the chamber with a high-pressure transformer and capacitor. To prevent instrument failure due to high temperature during continuous operation of the magnetron, a fan motor was attached. Thermistors were attached to the body and magnetron to cut power when the chamber overheated.

Using a single microwave chamber, a hydro-extractor was constructed. The experimental set was divided into 4 parts: a microwave chamber, filter set, impinger set, and vacuum pump. The microwave chamber had a 400 -mm width, 380-mm length, and 350-mm height (see Fig. 1).

Extracted moisture from the microwave was captured by 


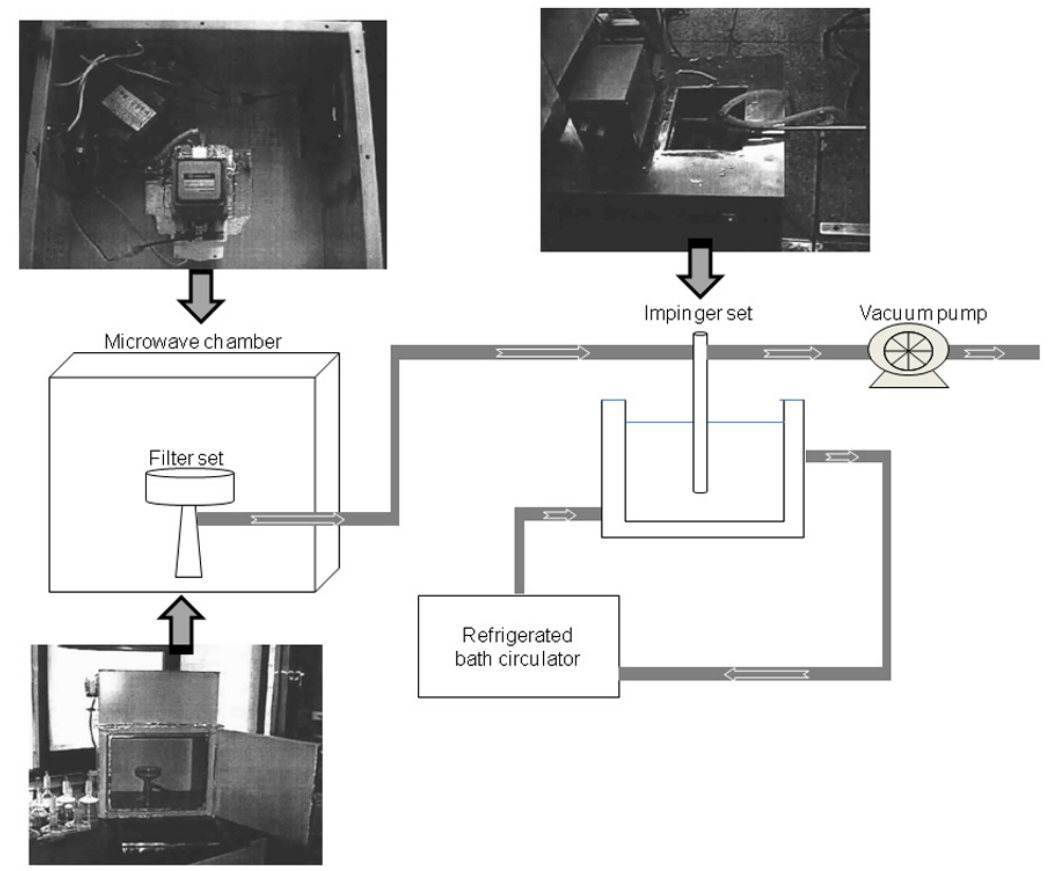

Figure 1

The schematic diagram and photographs of microwavedewatering system

a gas filter set. The impinger set was attached to minimise the loss of moisture. To condense the moisture, the temperature of the water in the impinger set was maintained at $0.5^{\circ} \mathrm{C}$ using a refrigerated bath circulator, and the total dehydration rate was measured, combining the amount of water in the impinger and filter sets. Glass filters were manufactured in various sizes to determine the range of sludge sizes in a real plant, and the filter pore size was $40 \sim 50 \mu \mathrm{m}$. To capture the extracted moisture, a vacuum pump was installed on the outside of the microwave chamber. A microwave detector was installed to measure the microwaves that leaked from the chamber. No microwave leakage was detected.

The frequency and microwave intensity were fixed at 2.45 $\mathrm{GHz}$ and $0.7 \mathrm{~kW}$, respectively. The dewatering efficiency was measured by sludge thickness (3-10 mm), sludge size (65-150 $\mathrm{mm})$, irradiation time (30-180 s), and vacuum pressure (0-100 $\mathrm{mm} \mathrm{Hg}$ ). To examine the effects of the vacuum on dewatering efficiency, the same test was conducted under non-vacuum conditions.

\section{Pilot-scale test of sludge dewatering using microwaves}

The microwave reactor was manufactured as a multimode cavity structure to achieve a 50t/d dehydration rate. A multimode cavity structure is mechanically simple and easy to heat uniformly over a wide range of reactor area. Despite the base frequency of a commercial magnetron being $2.45 \mathrm{GHz}$, it does not produce a single continuous frequency. Thus, multiple modes exist in the chamber.

At the top of the chamber, a rectangular wave guide was installed to convert the microwave from the magnetron to the chamber without loss. To adjust the effective impedance between the magnetron and chamber, the entire impedance of the system was calculated, and an adjustment wave guide was designed using the calculated impedance. As a result, the size of the wave guide was $86 \mathrm{~mm} \times 43 \mathrm{~mm} \times 86.4 \mathrm{~mm}$. The quantity of the sludge was $1.9 \mathrm{~kg}$, and the power was fixed at $0.8 \mathrm{~kW}$ and $2.7 \mathrm{~kW}$. The moisture content and power density were measured by irradiation time.

\section{Analysis}

To evaluate the volatilisation of volatile organic compounds in sludge, caloric values were measured on a calorimeter (Parr 1261 Bomb, Parr Instrument Co., Moline, IL, USA) before and after microwave treatment. To determine the distribution of liquid and vapour quantity in the total dewatered quantity, the moisture content and quantity of liquid were measured after the dewatering. Vapour quantity was calculated by subtracting the liquid quantity from total dewatering quantity. Because the moisture that was trapped in the capturing tube evaporated due to the microwave, an impinger was installed outside of the microwave generator to compensate for this. To condense the vapour that passed through the impinger, a refrigerated bath circulator was used to maintain the water temperature at $0.5^{\circ} \mathrm{C}$. The total liquid quantity was calculated by adding the moisture content in the liquid capturing tube to that in the impinger.

Water content and chemical oxygen demand (COD) were measured per standard methods (APHA et al., 1998). Degree of sludge disintegration was defined by Li et al. (2008), comparing the microwave process and maximum soluble chemical demand $\left(\mathrm{SCOD}_{\mathrm{NaOH}}\right)$.

Sludge disintegration degree $(\%)=\frac{\mathrm{SCOD}_{\mathrm{S}}-\mathrm{SCOD}_{\mathrm{S} 0}}{\mathrm{SCOD}_{\mathrm{NaOH}}-\mathrm{SCOD}_{\mathrm{S} 0}} \times 100$

$\mathrm{SCOD}_{\mathrm{S}}$ and $\mathrm{SCOD}_{\mathrm{S} 0}$ values are for treated and untreated sludge samples, respectively. $\mathrm{SCOD}_{\mathrm{NaOH}}$ was obtained by alkaline hydrolysis, wherein the initial sludge sample was mixed with $0.5 \mathrm{M} \mathrm{NaOH}$ at room temperature for $24 \mathrm{~h}$ (Feng et al., 2009b).

\section{RESULTS AND DISCUSSION}

\section{Dewatering of sludge using emulsion of sludge and diesel}

To select the optimal surfactant, 4 types of surfactants were used: amphoteric, anionic, emulsifier, and polymeric. As shown in Table 1, the amphoteric surfactant had the highest dewatering efficiency- 3 times that of the others-with a high affinity for water and oil in sludge. When amphoteric surfactant was 


\begin{tabular}{|c|c|c|c|c|c|}
\hline \multicolumn{6}{|c|}{$\begin{array}{c}\text { TABLE } 1 \\
\text { Characteristics of moisture rates under various conditions of emulsion (agitation speed: } \\
2500 \mathrm{r} / \mathrm{min} \text {, agitation time: } 20 \mathrm{~min} \text { ) }\end{array}$} \\
\hline Surfactant type & $\begin{array}{c}\text { Surfactant } \\
\text { content } \\
\text { (wt } \%)\end{array}$ & $\begin{array}{l}\text { Ratio of sludge } \\
\text { and diesel }\end{array}$ & $\begin{array}{l}\text { Reaction } \\
\text { temperature } \\
\left({ }^{\circ} \mathrm{C}\right)\end{array}$ & $\begin{array}{l}\text { Removed } \\
\text { moisture } \\
\text { content } \\
\text { (g) }\end{array}$ & $\begin{array}{l}\text { Calculated } \\
\text { moisture rate } \\
(w t \%)\end{array}$ \\
\hline Amphoteric & \multirow{4}{*}{1.5} & \multirow{4}{*}{$1: 5$} & \multirow{4}{*}{30} & 10.6 & 78.3 \\
\hline Anionic & & & & 2.90 & 81.8 \\
\hline Emulsifier & & & & 1.28 & 82.5 \\
\hline Polymeric & & & & 2.31 & 82.1 \\
\hline \multirow{3}{*}{ Amphoteric } & 1.5 & \multirow{3}{*}{$1: 5$} & \multirow{3}{*}{30} & 10.6 & 78.3 \\
\hline & 2.0 & & & 11.3 & 77.9 \\
\hline & 3.0 & & & 5.86 & 80.6 \\
\hline \multirow{3}{*}{ Amphoteric } & \multirow{3}{*}{1.5} & $1: 5$ & \multirow{3}{*}{30} & 11.4 & 77.7 \\
\hline & & $1: 3$ & & 14.2 & 78.9 \\
\hline & & $1: 2$ & & 6.86 & 79.7 \\
\hline \multirow{3}{*}{ Amphoteric } & \multirow{3}{*}{1.5} & \multirow{3}{*}{$1: 5$} & 10 & 14.7 & 78.4 \\
\hline & & & 30 & 14.3 & 78.6 \\
\hline & & & 50 & 6.16 & 79.4 \\
\hline
\end{tabular}

\begin{tabular}{|c|c|c|c|c|c|c|}
\hline \multicolumn{7}{|c|}{$\begin{array}{c}\text { TABLE } 2 \\
\begin{array}{c}\text { Characteristics of moisture removal rates under various conditions for additives (surfactant: amophoteric type, surfactant } \\
\text { content: } 1.5 \mathrm{wt} \% \text {, reaction temperature: } 30^{\circ} \mathrm{C} \text { ) }\end{array}\end{array}$} \\
\hline Additive type & $\begin{array}{l}\text { Additive content } \\
\text { (g) }\end{array}$ & $\begin{array}{l}\text { Ratio of sludge } \\
\text { and diesel }\end{array}$ & $\begin{array}{l}\text { Agitation speed } \\
(\mathrm{r} / \mathrm{min})\end{array}$ & $\begin{array}{l}\text { Agitation time } \\
\quad(\min )\end{array}$ & $\begin{array}{c}\text { Removed } \\
\text { moisture content } \\
(\text { (g) }\end{array}$ & $\begin{array}{l}\text { Calculated } \\
\text { moisture rate } \\
(w t \%)\end{array}$ \\
\hline Surfactant alone & - & \multirow{3}{*}{$1: 5$} & \multirow{3}{*}{2500} & \multirow{3}{*}{20} & 14.2 & 78.9 \\
\hline Methanol alone & 30 & & & & 12.3 & 79.5 \\
\hline Surfactant + methanol & 30 & & & & 34.1 & 68.7 \\
\hline \multirow{3}{*}{ Surfactant + methanol } & 30 & \multirow{3}{*}{$1: 5$} & \multirow{3}{*}{2500} & \multirow{3}{*}{20} & 34.7 & 67.8 \\
\hline & 50 & & & & 38.3 & 64.9 \\
\hline & 75 & & & & 43.3 & 59.1 \\
\hline \multirow{3}{*}{ Surfactant + methanol } & \multirow{3}{*}{75} & $1: 5$ & \multirow{3}{*}{2500} & \multirow{3}{*}{20} & 41.8 & 60.6 \\
\hline & & $1: 3$ & & & 47.2 & 53.1 \\
\hline & & $1: 2$ & & & 40.5 & 65.4 \\
\hline \multirow{3}{*}{ Surfactant + methanol } & \multirow{3}{*}{75} & \multirow{3}{*}{$1: 3$} & 500 & \multirow{3}{*}{20} & 39.1 & 63.9 \\
\hline & & & 1200 & & 48.3 & 51.1 \\
\hline & & & 2500 & & 45.3 & 57.3 \\
\hline \multirow{3}{*}{ Surfactant + methanol } & \multirow{3}{*}{75} & \multirow{3}{*}{$1: 3$} & \multirow{3}{*}{1200} & 20 & 48.2 & 51.5 \\
\hline & & & & 40 & 43.3 & 59.1 \\
\hline & & & & 60 & 40.5 & 65.4 \\
\hline
\end{tabular}

added to $2 \%$, the dewatering efficiency was relatively high, but the amounts of water that were removed declined as surfactant content increased, indicating that excessive surfactant inhibits the formation of emulsions.

Next, we examined the optimal ratio of sludge and diesel for the pre-conditioning sludge using amphoteric surfactant. At a ratio of sludge to diesel of 1:3, the dewatering efficiency peaked, as evidenced by the significant amounts of water replaced by diesel. As the ratio of sludge and diesel decreased, the filtration time lengthened, implying that the viscosity of the mixture significantly affects filtration time. In addition, at higher reaction temperatures, less moisture was removed, but there was little change in dewatering efficiency below $30^{\circ} \mathrm{C}$, indicating that reactions at room temperature are effective.

When sludge and diesel were mixed, the moisture contained in the sludge formed an emulsion with diesel and the water in the sludge was removed, because the position of the moisture in the sludge was occupied by diesel. The diesel was then replaced by methanol as a low boiling-point solvent. In the sludge, only solid-phase sludge, residual water and methanol remained. Since the methanol contained in sludge can be removed easily by heating and decompression, a high efficiency of sludge dewatering can be obtained.

In the experiment above, the dewatering efficiency of sludge decreased by $5 \%$, which is insufficient for sludge reduction and energy efficiency in the incineration process. Thus, as shown in Table 2, moisture removal efficiency was at least 2 -fold higher when a low-boiling-point solvent, such as methanol, was used as an additive to the surfactant, relative to when the surfactant or additive was used alone. This finding indicates that the surfactant and additive have synergistic effects, enhancing moisture removal significantly. One reason 
for this improvement is the consequent reduction in extracellular polymeric substances and the resulting compactness of the sludge (Chen et al., 2001).

With the additive, an oil-sludge ratio of 1:3 effected the greatest moisture removal, as occurred without the additive. The dewatering effect also varied with agitation conditions and the manner in which the additive was supplied. With the additive, the moisture content was $60 \%$ or lower at a fixed agitation speed of $1200 \mathrm{r} / \mathrm{min}$, and the dewatering effect rose with increases in the quantity of additive. Longer agitation times reduced the dewatering effect.

In summary, to improve the dewatering efficiency of an emulsion of sludge and oil, a low-boiling-point additive must be added, such as methanol, at a constant agitation speed of $1200 \mathrm{r} / \mathrm{min}$ for $20 \mathrm{~min}$. The sludge-oil emulsion reduced the moisture content in sludge to $60 \%$ or lower, implying that it can lower incineration costs, because it allows direct incineration of products. However, it is economically infeasible for use in largescale commercial facilities due to the complexity of the process and the requirement of additional facilities for the recovery of methanol and oil.

\section{Dewatering of sludge using ultrasonic waves}

To indirectly examine the dewatering effect in the cell using a $40 \mathrm{kHz}$ and $0.2 \mathrm{~kW}$ ultrasonic oscillator, we measured the change in SCOD concentration and moisture content after decomposition of $98 \%$ thickened sludge at various reaction times and powers. Figure $2 \mathrm{a}$ shows the effect of ultrasonic power on the SCOD of concentrated sludge after $1 \mathrm{~h}$ of irradiation. When the power exceeded $0.1 \mathrm{~kW}$, SCOD values increased to $1850 \mathrm{mg} / \ell$ at $0.18 \mathrm{~kW}$ or higher -6 times greater than the initial value of $300 \mathrm{mg} / \ell$. Next, the SCOD remained nearly constant despite an increase in power. Cells were destroyed by ultrasonic irradiation over the specific time and intensity, and the moisture was discharged to the outside. This result indicates that the moisture content in sludge can be removed after ultrasonic treatment and filtration.

Ultrasonic treatment can disintegrate sludge and release the organic matter in the flocs. Low density and long duration sonication was more efficient than high density and short duration. The effect of temperature rise was limited at low energy density when sonication time was short (Huan et al., 2009). When the activated sludge was disintegrated with ultrasound, cell membranes were disrupted, releasing intracellular polysaccharides and proteins into the extracellular matrix and thereby leading to the observed increase in EPS levels (Zhang et al., 2007). Wang et al. (2006) similarly concluded that ultrasonic sludge disintegration significantly increased the concentration of soluble biopolymers.

Figure $2 \mathrm{~b}$ shows the effect of ultrasonic time on the SCOD of concentrated sludge at $160 \mathrm{~W}$. SCOD values did not change significantly until after $1 \mathrm{~h}$ of irradiation, at which point they rose abruptly, indicating that it took more than $1 \mathrm{~h}$ for cells to be destroyed and that the sonic wave irradiation had to exceed $1 \mathrm{~h}$ to ensure the dewatering effect by discharging the moisture from the cell at $160 \mathrm{~W}$. If the intensity of ultrasonic waves increases, the irradiation time for cell destruction can be reduced.

As shown in Fig. 2c, higher intensities increased the dewatering efficiency, and ultrasonic wave irradiation increased the moisture removal efficiency by approximately $8 \%$. This result implies that the particles of sludge are pulverised by sonic waves and the overall pore moisture in sludge increased.
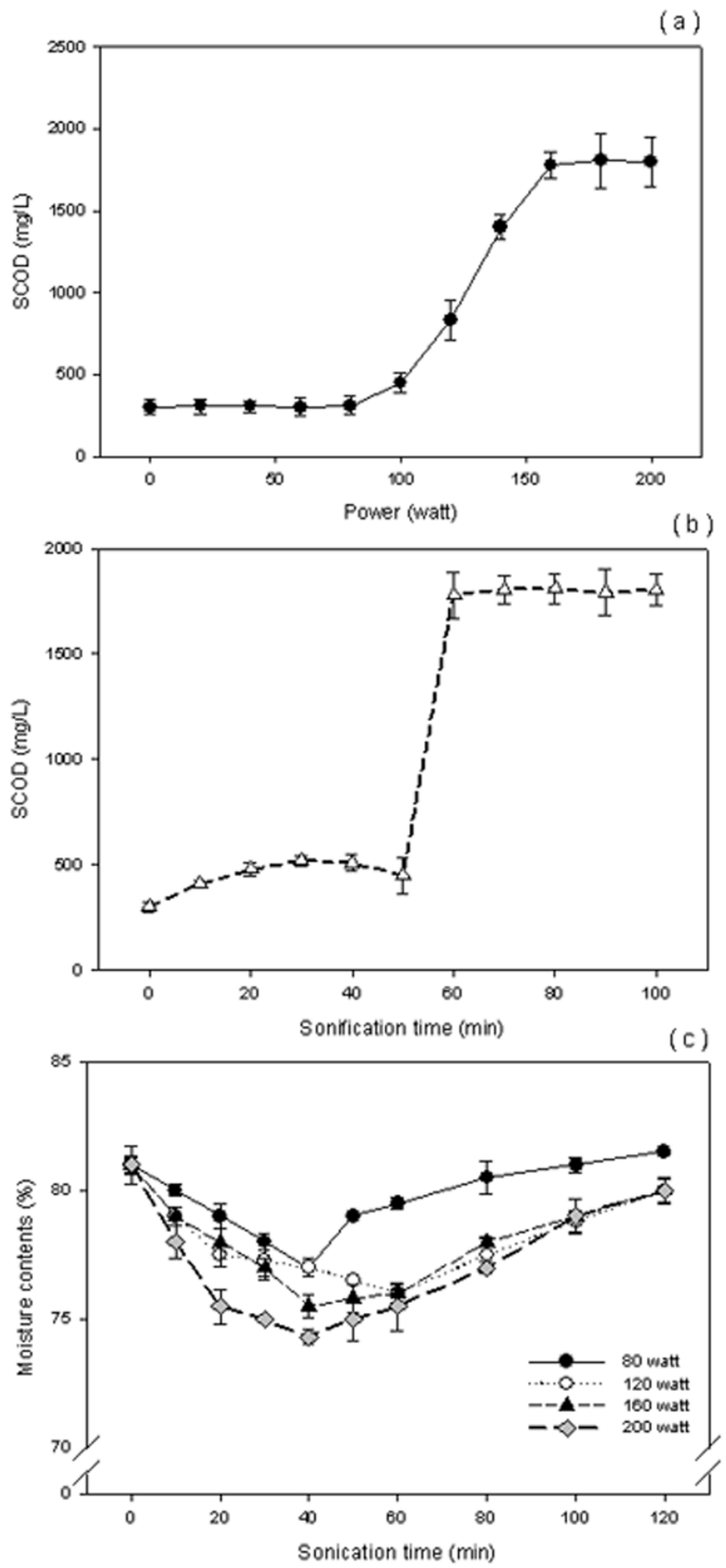

Figure 2

The effect of (a) ultrasonic power and (b) ultrasonic time on the SCOD of sewage sludge and (c) the effect of ultrasonic power and time on moisture content

After 40 to 60 min of irradiation, moisture removal efficiency increased, and thereafter declined. This phenomenon can be explained by the gradual increase in moisture content with sonication time.

Sludge dewatering technology using sonication reduced the moisture content to $74 \%$, requiring $30 \mathrm{~min}$ of sonication time or longer. It is unlikely that this technique will be applied in actual treatment plants, due to the low dewatering and energy efficiencies despite the relatively long sonication time. 

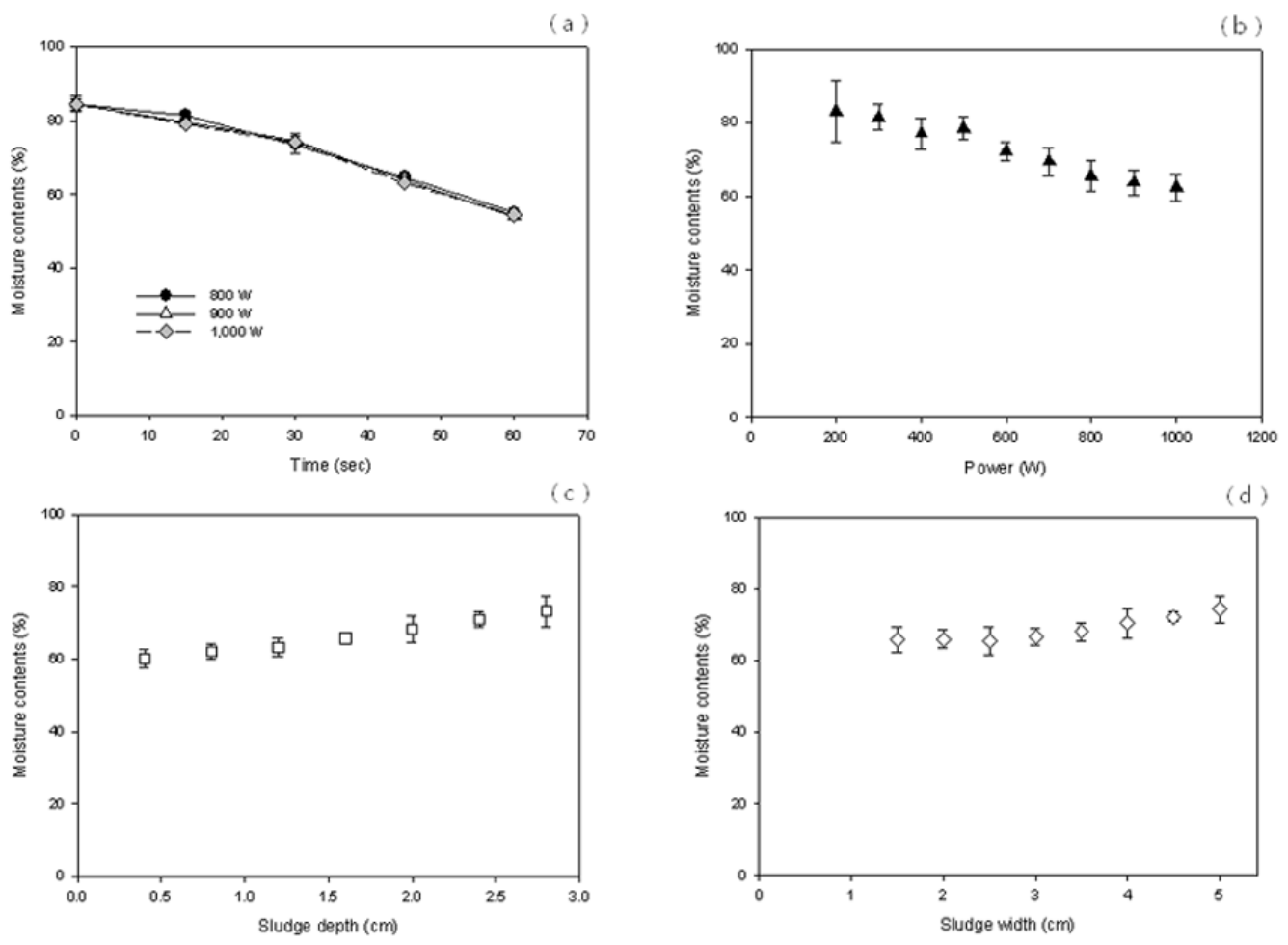

Figure 3

The effect of (a) radiation time, (b) power intensity (radiation time $=45 \mathrm{~s})$, (c) sludge thickness (radiation time $=45 \mathrm{~s}$, power $=0.9 \mathrm{~kW}$ ), and (d) sludge width (radiation time $=45$ s, power $=0.9$ $\mathrm{kW}$ ) on moisture content of sewage sludge.

\section{Dewatering of sludge using microwaves}

\section{Feasibility test}

The dewatering efficiency of sludge using microwaves was measured for a range of microwave intensities and times. The dewatering efficiencies did not change when the power intensity rose from $0.8 \mathrm{~kW}$ to $1.0 \mathrm{~kW}$. When the irradiation time increased from 10 to $60 \mathrm{~s}$, the sludge moisture decreased to $60 \%$ within 30 to $45 \mathrm{~s}$ (see Fig. 3a). When the irradiation time was fixed at $45 \mathrm{~s}$, which could have resulted in $60 \%$ or less sludge moisture, and the power intensity climbed from $0.2 \mathrm{~kW}$ to $1.0 \mathrm{~kW}$, the power intensity became inversely proportional to the moisture content. At $0.6 \mathrm{~kW}$ or less, the moisture content became $70 \%$ or higher, indicating that this condition was unsuitable for dewatering sludge (see Fig. 3b).

The experiments were conducted to evaluate dewatering efficiency under various thickness of sludge, showing that the dewatering efficiency reduced as sludge got thicker. The results indicate that microwave has a limitation in the penetration of sludge used in this study (see Fig. 3c). In order to increase sludge dewatering efficiency by microwave, the thickness of sludge needs to decrease.

The dewatering efficiency by sludge sample area was examined with 20-mm-thick sludge. As shown in Fig. 3d, the dewatering efficiency was constant until the sludge sample area reached $30 \mathrm{~mm}$, above which the efficiency declined, because the power distribution in the microwave reactor was normally from the centre of the sample. As the sludge area increased, the distance from the centre rose and the power fell, indicating that the power distribution must be simulated before the dewatering device can be designed.

Based on the calculation of the material balance before and after dewatering using the microwave, most of the dewatering occurred due to evaporation (data not shown). In addition, as evidenced by the lower heating value before and after the dewatering, the dewatering led to a slight increase in heating value. There was no decrease in heating value due to the volatilisation of organic substances in the sludge (data not shown).

\section{Lab-scale test}

Based on the results of the feasibility test, the microwave was used on sludge to determine the dewatering efficiency by irradiation time, sludge thickness, sludge area (size), and vacuum pressure. The dewatering efficiency of the suctioned sludge was compared with that of non-suctioned sludge according to irradiation time. Although the moisture content did not change with irradiation time, the liquid portion of the sludge rose as irradiation time increased, as shown in Fig. 4a, indicating that longer irradiation times increase the quantity of liquid due to the decrease in moisture content. The effect of the suction was more robust for the liquid portion than vapour. To achieve a moisture content of $60 \%$ or less, the irradiation time was fixed at $120 \mathrm{~s}$ in all subsequent tests.

As shown in Fig. 4b, the dewatering efficiency declined gradually as the sludge thickness increased with the suction, but without the suction, the dewatering efficiency remained nearly constant. This result suggests that with the suction the filter was blocked by the vacuum before the moisture evaporated around the filter, and the area beyond the reach of the microwave increased, reducing the dewatering efficiency. In addition, the liquid portion was unaffected by the rise in sludge thickness but differed significantly, based on use of the suction. Based on the result that reducing the thickness of the sludge increases the dewatering efficiency, a sludge thickness of $5 \mathrm{~mm}$ or less is required to ensure $60 \%$ moisture content or lower.

Within a range of $2.7-13.3 \mathrm{kPa}$, an increase in vacuum pressure did not change the moisture content in sludge, but the liquid portion with the suction rose in proportion to the vacuum pressure (see Fig. 4c). Accordingly, it appears that 

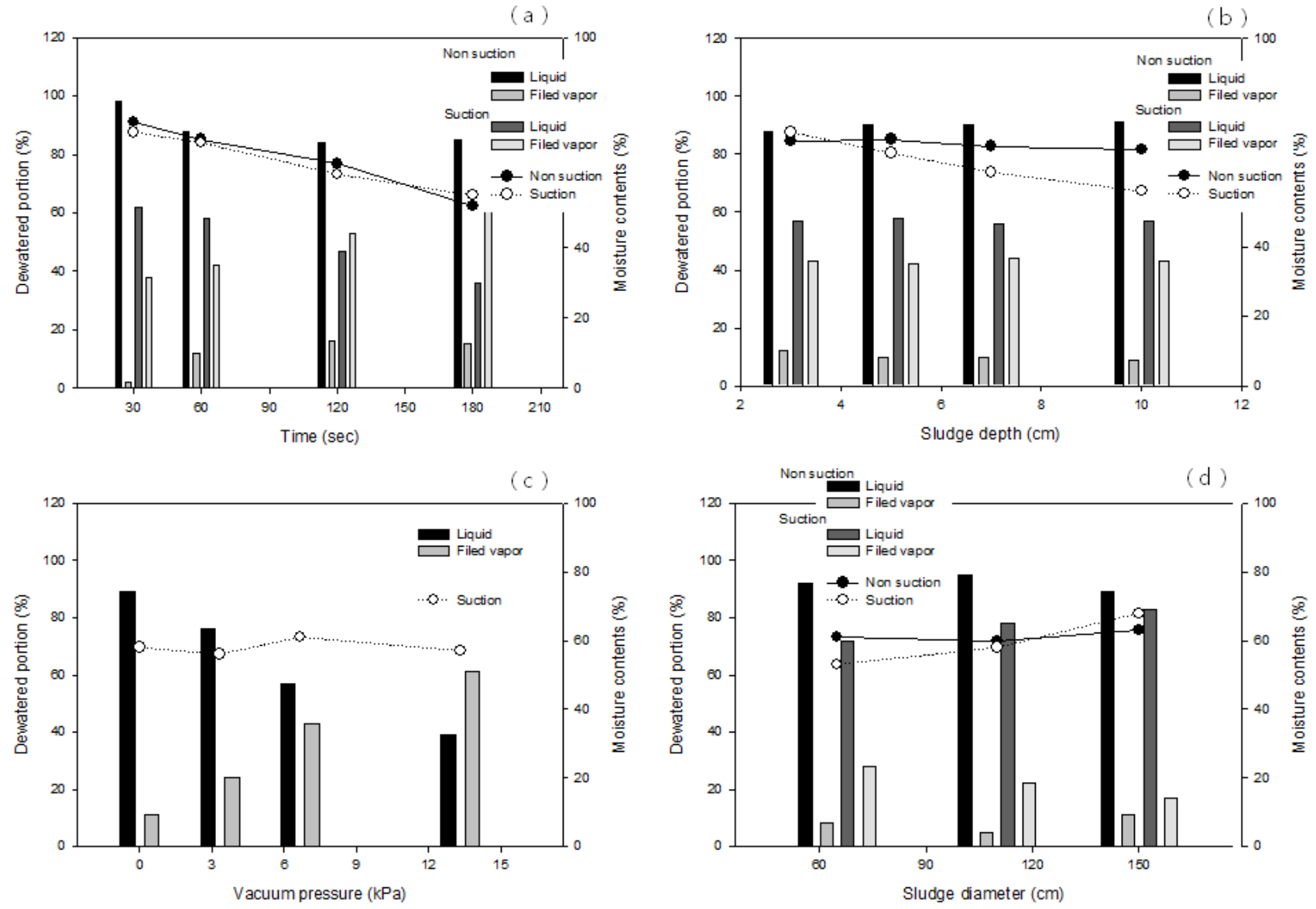

Figure 4

The effect of (a) radiation time (power $=0.9 \mathrm{~kW}$, sludge size $=3 \times 65 \mathrm{~mm}$, vacuum pressure $=3.3 \mathrm{kPa}$ ), (b) sludge thickness (power $=0.9 \mathrm{~kW}$, sludge diameter $=65 \mathrm{~mm}$, time $=120 \mathrm{~s}$, vacuum pressure $=3.3 \mathrm{kPa}$ ), (c) vacuum pressure (power $=0.9 \mathrm{~kW}$, sludge size $=3 \times 65 \mathrm{~mm}$, time $=120 \mathrm{~s})$, and $(d)$ sludge diameter (power $=0.9 \mathrm{~kW}$, sludge depth $=3$ $\mathrm{mm}$, time $=120 \mathrm{~s}$, vacuum pressure $=3.3 \mathrm{kPa}$ ) on the dewatered portion of sewage sludge (line indicates moisture content with and without suction).

suction with a vacuum is suitable for reducing the energy that is required to evaporate the moisture from dewatering. Because moisture content hardly affects vacuum pressure, a pressure of $3.3 \mathrm{kPa}$ is feasible.

Dewatering efficiencies with varying sludge size (diameter) and thickness were similar. Larger sludge size decreased the dewatering efficiency, because the microwave did not reach as many parts of the sludge. The liquid portion with and without suction did not differ. However, thicker sludge increased the liquid portion, whereas larger sludge decreased it. These data indicate that sludge size influences the liquid portion more significantly than sludge thickness. In conclusion, thinner and smaller sludge increases dewatering efficiency.

\section{Pilot-scale test}

As shown in Fig. $5 \mathrm{a}$, when the power increased from $0.8 \mathrm{~kW}$ to $1.4 \mathrm{~kW}$, the time to reach a moisture content as low as $54 \%$ was approximately 1.7 -fold faster. Figs. $5 \mathrm{~b}$ and $5 \mathrm{c}$ show the change in energy input per remaining moisture content and the change in remaining moisture content in the sludge by microwave irradiation time. The initial moisture content of $1.9 \mathrm{~kg}$ of municipal wastewater sludge was $83 \%$ (i.e., $1.58 \mathrm{~kg}$ ). With microwave irradiation, the moisture content continued to decrease by dewatering to approximately $0.40 \mathrm{~kg}$ in $50 \mathrm{~min}$. Thus, the moisture content in sludge, which was directly influenced by the microwave energy, declined, and the decrease in microwave energy per remaining water content accelerated, increasing the input power density and decreasing the drying time.

Figure $5 \mathrm{~d}$ shows the energy input per unit of moisture removed. As microwave irradiation time increased, the energy consumption per unit moisture that was removed from the sludge fell. In dewatering with the microwave, the moisture content in sludge declined as microwave irradiation time increased, and the input microwave energy decreased sequentially with the reduction in moisture content. The energy consumption was $0.57 \mathrm{kWh} / \mathrm{kg}$ of removed water; the specific energy consumptions in the dewatering methods are summarised in Table 3.

Figure 6 shows the quantities of liquid and vapour that were removed from the bottom and top of the reactor, respectively, with irradiation time, in the microwave irradiation method. Most moisture that was removed from the municipal wastewater sludge was in vapour form. With increasing irradiation time, the moisture that was removed directly in liquid form decreased gradually but levelled off at approximately $10 \%$ after $30 \mathrm{~min}$. As the power rose, the removal of the initial moisture in liquid form increased. In addition, the power consumption declined, because it decreased the removal of vapour. Thus, in the design of a large facility, the microwave 


\begin{tabular}{|l|l|l|l|}
\hline \multicolumn{5}{|c|}{ Energy consumption of sludge dewatering methods } \\
\hline Dewatering Method & Material & $\begin{array}{l}\text { Specific energy consumption } \\
\text { (kWh/kg of removed water) }\end{array}$ & Reference \\
\hline Electroosmotic & Bentonite & 0.70 & Larue et al. (2006) \\
\hline Electro-dewatering & Waste-activated sludge & 0.25 & Citeau et al. (2011) \\
\hline Electroosmotic & Waste-activated sludge & $0.013-0.119$ & Zhou et al. (2001) \\
\hline Electroosmotic & Composted wastewater sludge & 0.66 & Banerjee and Law (1998) \\
\hline Microwave & Waste-activated sludge & 0.54 & This study \\
\hline
\end{tabular}
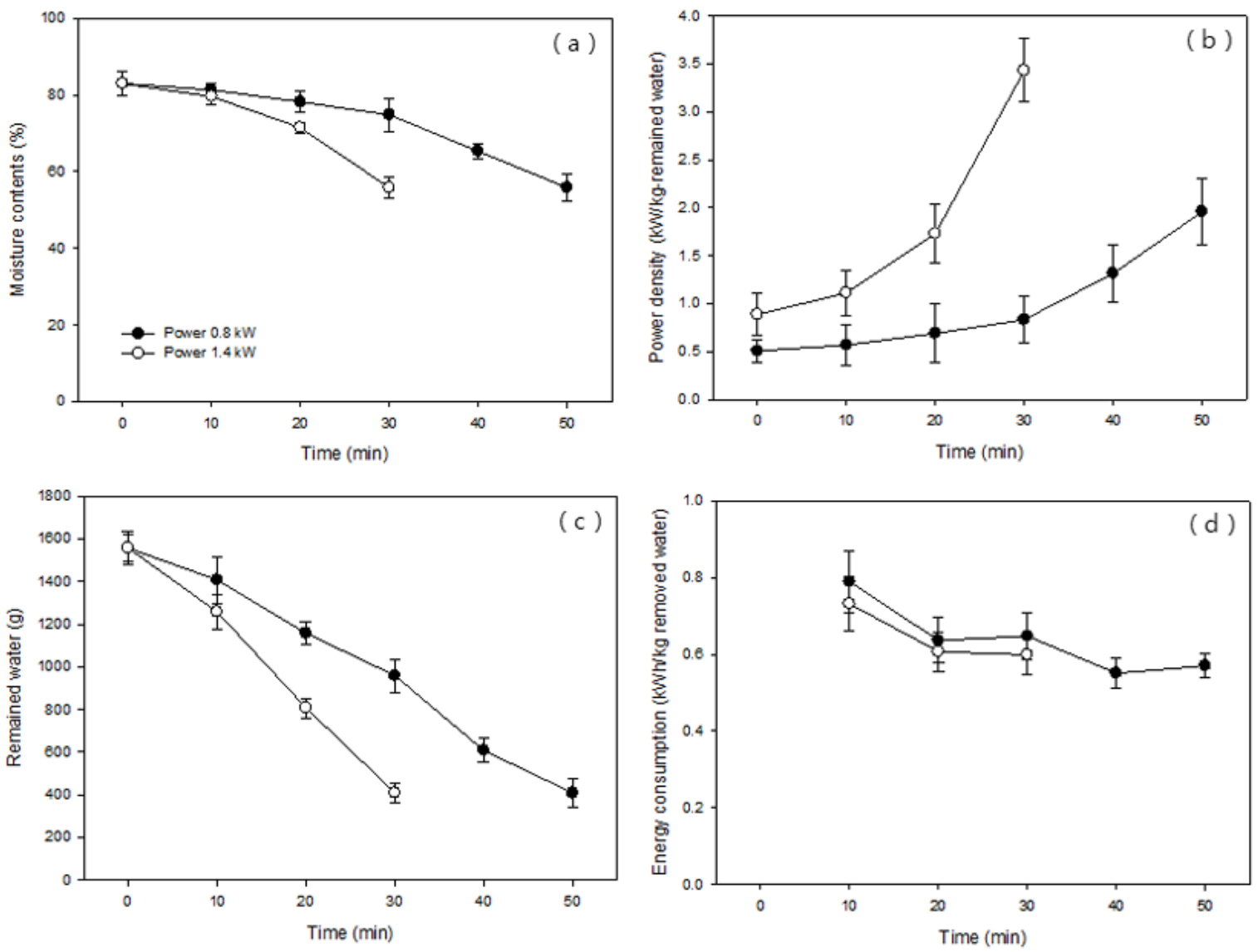

Figure 5 (above)

Change in moisture content, power density, remaining water, and energy consumed per unit water removed with time (sludge weight $=1.9 \mathrm{~kg}$, initial moisture contents $=83 \%$ ).

power should be increased to enhance the removal of moisture in the sludge in the form of liquid rather vapour.

\section{CONCLUSIONS}

An innovative sludge dewatering technology is required to enhance sludge recycling, in light of the ban on direct landfill and ocean disposal. Dewatering technologies that use chemicals and electrical waves have tremendous potential to decrease the moisture content, as an alternative to physical methods. This study examined 3 types of dewatering technologies (sludge/oil emulsion, ultrasonication, and microwave). Ultrasonication technology has limitations, such as low dewatering efficiency and low energy efficiency, despite long

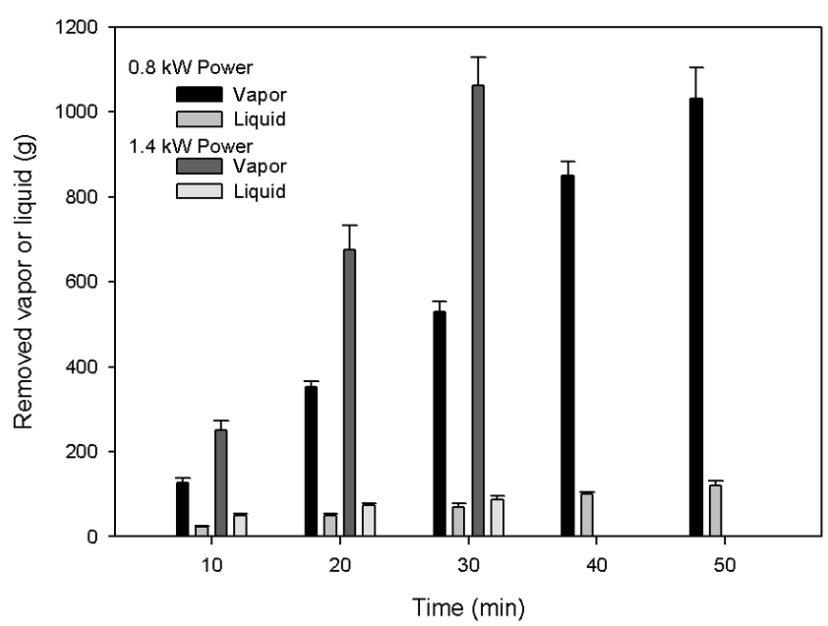

Figure 6

Liquid and vapour portion of removed water in sludge over time (sludge weight $=1.9 \mathrm{~kg}$, initial moisture content $=83 \%$ ) 
required sonication times under $160 \mathrm{~W}$ ultrasonic intensity. In contrast, the sludge/oil emulsion reduced the moisture content in sludge to $60 \%$ or less, but was not cost-effective with regard to the initial investment and operation. Lastly, the microwave technology displayed high dewatering efficiency, and its optimal operational factors - irradiation time, sludge thickness, sludge area, and vacuum pressure - were $120 \mathrm{~s}$, depth $<3 \mathrm{~mm}$, diameter $<60 \mathrm{~mm}$, and $<3.3 \mathrm{kPa}$, respectively. Also, the liquid portion was not affected by increases in sludge thickness or size but differed significantly, based on use of the suction. In a pilotscale microwave plant, the dewatering efficiency was confirmed to enhance moisture removal in liquid and vapour form. Thus, microwave technology is a powerful tool that minimises energy consumption and improves dewatering efficiency for municipal wastewater sludge.

\section{ACKNOWLEDGEMENT}

This study was supported by a National Research Foundation of Korea (NRF) grant funded by the Korean Government (NRF-2013R1A2A1A09007252).

\section{REFERENCES}

APHA, WEF and AWWA (1998) Standard Methods for the Examination of Water and Wastewater (20 $\left.0^{\text {th }} \mathrm{edn}\right)$. American Public Health Association/American Water Works Association/Water Environment Federation, Washington DC.

BANERJEE S and LAW SE (1998) Electroosmotically enhanced drying of bionzass. IEEE Trans. Ind. Appl. 34 992-999.

CHEN Y, YANG H and GU G (2001) Effect of acid and surfactant treatment on activated sludge dewatering and settling. Water Res. $352615-2620$.

CHITIKELA S and DENTEL SK (1998) Dual-chemical conditioning and dewatering of anaerobically digested biosolids: Laboratory evaluations. Water Environ. Res. 70 1062-1069.

CHIU Y, CHANG C, LIN J and HUANG S (1997) Alkaline and ultrasonic pretreatment of sludge before anaerobic digestion. Water Sci. Technol. 36 155-162.

CITEAU M, LARUE $\mathrm{O}$ and VOROBIEV E (2011) Influence of salt, $\mathrm{pH}$ and polyelectroyte on the pressure electro-dewatering of sewage sludge. Water Res. 45 2167-2180.

DENTEL SK (2010) Chemical conditioning for solid-liquid separation processes. Dry. Technol. 28 843-849.

DEWIL R, BAEYENS J and GOUTVRINF R (2006) Ultrasonic treatment of waste activated sludge. Environ. Prog. 25 (2) 121-128.

DOĞAN I and SANIN FD (2009) Alkaline solubilization and microwave irradiation as a combined sludge disintegration and minimization method. Water Res. 43 2139-2148.

ESKICIOGLU C, TERZIAN N, KENNEDY KJ, DROSTE R and HAMODA M (2007) Athermal microwave effects for enhancing digestibility of waste activated sludge. Water Res. 41 2457-2466.

FAKHRU'L-RAZI A and MOLLA AH (2007) Enhancement of bioseparation and dewaterability of domestic wastewater sludge by fungal treated dewatered sludge. J. Hazardous Mater. 147 350-356.

FENG X, DENG J, LEI H, BAI T, FAN Q and LI Z (2009a) Dewaterability of waste activated sludge with ultrasound conditioning. Bioresour. Technol. 100 1074-1081.

FENG X, LEI H, DENG J, YU Q and LI HL (2009b) Physical and chemical characteristics of waste activated sludge treated ultrasonically. Chem. Eng. Process 48 187-194.

GRÖNROOS A, KYLLONEN H, KORPIJARVI K, PIRKONEN P, PAAVOLA T, JOKELA J and RINTALA J (2005) Ultrasound assisted method to increase soluble chemical oxygen demand (SCOD) of sewage sludge for digestion. Ultrason. Sonochem. 12 115-120.

HOGAN F, MORMEDE S, CLARK P and CRANE M (2004) Ultrasonic sludge treatment for enhanced anaerobic digestion. Water Sci. Technol. 50 25-32.

HUAN L, YIYING J, MAHAR RB, ZHIYU W and YONGFENG N (2009) Effects of ultrasonic disintegration on sludge microbial activity and dewaterability. J. Hazardous Mater. 161 1421-1426.

LARUE O, WAKEMAN RJ, TARLETON ES and VOROBIEV E (2006) Pressure electroosmotic dewatering with continuous removal of electrolysis products. Chem. Eng. Sci. 61 4732-4740.

LEE CH and LIU JC (2001) Sludge dewaterability and floc structure in dual polymer conditioning. Adv. Environ. Res. 5 129-136.

LI H, JIN YY, MAHAR RB, WANG Z and NIE YF (2008) Effects and model of alkaline waste activated sludge treatment. Bioresour. Technol. 99 5140-5144.

MASON TJ (1991) Practical Sonochemistry: User's Guide to Applications in Chemistry and Chemical Engineering. Ellis Horwood Limited, Herts.

MOE (MINISTRY OF ENVIRONMENT, KOREA) (2003) Prohibition of Direct Landfill of Organic Sludge (Addenda 97, Article 2, the enforcement of the Wastes Control Act). 1 July 2003. Ministry of Environment in Korea, Seoul.

MOF (MINISTRY OF OCEANS AND FISHERIES, KOREA) (2009)

Law of Ocean Environment Management (Addenda 23, ocean dumping prohibition of wastes). 3 January 2009. Ministry of Oceans and Fisheries in Korea, Seoul.

NA S, KIM YU, KHIM J (2007) Physiochemical properties of digested sewage sludge with ultrasonic treatment. Ultrason. Sonochem. 14 281-285.

NEYENS E, BAEYENS J, DEWIL R and DE HEYDER B (2004) Advanced sludge treatment affects extracellular polymeric substances to improve activated sludge dewatering. J. Hazardous Mater. 106 83-92.

RAATS MHM, VAN DIEMEN AHG, LAVEN J and STEIN HN (2002) Full scale electrokinetic dewatering of waste sludge. Colloid Surf. A 210 231-241.

TONY MA, ZHAO YQ, FU JF and TAYEB AM (2008) Conditioning of aluminium-based water treatment sludge with Fenton's reagent: effectiveness and optimising study to improve dewaterability. Chemosphere 72 673-677.

WANG F, JI M and LU S (2006) Influence of ultrasonic disintegration on the dewaterability of waste activated sludge. Environ. Prog. 25 257-260.

WANG Q, KUNINOBU M, KAKIMOTO K, OGAWAA HI and KATO Y (1999) Upgrading of anaerobic digestion of waste activated sludge by ultrasonic pretreatment. Bioresour. Technol. 68 309-313.

WOJCIECHOWSKA E (2005) Application of microwaves for sewage sludge conditioning. Water Res. 39 4749-4754.

YU Q, LEI H, YU G, FENG X, LI Z and WU Z (2009) Influence of microwave irradiation on sludge dewaterability. Chem. Eng. J. 155 88-93.

ZHANG P, ZHANG G and WANG W (2007) Ultrasonic treatment of biological sludge: floc disintegration, cell lysis and inactivation. Bioresour. Technol. 98 207-210.

ZHOU J, LIU Z, SHE P and DING F (2001) Water removal from sludge in a horizontal electric field. Dry. Technol. 19627-638. 
http://dx.doi.org/10.4314/wsa.v40i4.13 Available on website http://www.wrc.org.za

ISSN 0378-4738 (Print) $=$ Water SA Vol. 40 No. 4 October 2014 ISSN 1816-7950 (On-line) = Water SA Vol. 40 No. 4 October 2014 